\title{
DETERMINING THE SUITABLE LOCATION FOR THE METALLURGICAL AND STEEL PROCESSING INDUSTRIES IN MONGOLIA USING GIS-BASED MULTI- CRITERIA ANALYSIS METHODS
}

\author{
Zolzaya Adiya $^{1,2}$, Battogtokh Dorjgotov ${ }^{1 *}$, Sainbuyan Bayarsaikhan ${ }^{1}$, Myagmartseren Purevtseren ${ }^{2}$ \\ ${ }^{1}$ Institute of Geography and Geoecology, Mongolian Academy of Sciences, Ulaanbaatar 15170, Mongolia- \\ zolzayaa@mas.ac.mn, battogtokh@mas.ac.mn, sainbuyanb@mas.ac.mn \\ ${ }^{2}$ Department of Geography, National University of Mongolia, Ulaanbaatar 14201-46A, Mongolia- \\ myagmartseren@num.edu.mn, zolzayaa@mas.ac.mn,
}

Commission IV, TC IV/3

KEY WORDS: GIS, AHP, Industrial site selection, Multi Criteria Decision Analysis, site suitability analysis, Mongolia

\begin{abstract}
:
The metallurgical and steel processing industries are considered strategically important industries as they form the basis of a country's industrial competitiveness and sustainable economy.

Recently, the value of minerals and demand for metals are increasing. Thus, it is essential to build a metallurgical and steel processing factory in Mongolia based on the needs of national consumption and neighboring countries market demand. Therefore, it is crucial to select a suitable geographical location for any industrial regional development based on scientific, spatial analysis and estimation. The main goal of our research study is to use MCDA and AHP methods based on GIS including natural conditions, resources, socioeconomic factors and other related data to identify suitable locations for metallurgical and steel processing factories in Mongolia. In order to determine the suitable location for metallurgical and steel processing industries research team used multi criteria analysis method including the total of 28 factors: 7 factors based on mineral resources and natural resources; 4 infrastructure factors, 2 market factors, 8 socio-economic factors, and 7 natural constraint factors based on area where industries and activities are prohibited in accordance with the legislation of Mongolia. According to the research results, 9.8 percent of the total area is highly suitable, 22.7 percent is suitable, 22.4 percent is unsuitable, and 68.8 percent is constraint area for industrial and steel processing industries. The result of the study shows that our assessment is precisely overlaps (kappa coefficient $=0.84$ ) with the location of existing metallurgical and steel industries and compatible with the regions where other projects and action program planning to build new industries in Mongolia.
\end{abstract}

\section{INTRODUCTION}

Mongolia's industrial sector structure is based on mining and agricultural raw materials and simple technologies and mining products alone account for 83.0 percent of exported products. In addition, 97 percent of exports are products without technological storage capacity and low-tech products (NSO, 2017), which shows that the competitiveness of our country's industrial sector is weak. In the last period of 2011-2016, Mongolia imported 60-100 main types of metal products, steel, and cast iron products, industrial equipment, machinery spare parts, and components by the 13.6 billion USD and it is an average of 2.7 billion USD per year, which accounts for $56-60 \%$ of Mongolia's total imports (Ministry of Industry, Mongolia, 2016).

Our country, which has 1 billion tons of ore reserves (MRPA, 2013), mines 572.2 thousand ton of iron ore and 386.4 thousand ton of iron ore concentrate (NSO, 2019) annually, but imports 7080 percent of domestic demand (Ministry of Industry, Mongolia, 2016) indicates the need to build a metallurgical and steel processing industry. In our country, which has a large area and low population density, population in urban areas is increasing year by year, and population in rural areas is decreasing is from one hand it has high economic significance, from other hands, it is important to establish an industrial region and an industrial park, which will reduce the urban agglomeration.

When locating the industry, many factors need to be considered to harmonize environmental sustainability such as to identify correctly territorial features and mineral resources, (Natsagdorj B., 1975) to consider the impact of external economic factors (Marzieh Reisi et al., 2011).

Many traditional theories determine the suitability of an industrial location and researchers are evaluating using methods such as MCDA and AHP based on the GIS (Hadeal H. Alzamili et al., 2015, Alexandre de Oliveira Gomes et al., 2015, Amita Johar et al., 2013, Marzieh Reisi et al., 2011, Aleksandar Rikalovic et al., 2014).

The use of GIS technology and methodology in determining the location of industrial sites allows for a wide range of industrial zone mapping, monitoring, and management (Amita Johar et al., 2013).

The main goal of our research study is to use MCDA and AHP methods based on GIS including mineral resources and natural resources, infrastructure, consumer markets, socio-economic factors and other related data to identify suitable locations for metallurgical and steel processing factories in Mongolia.

\section{MATERIAL AND METHODS}

\subsection{Study area}

Mongolia is located in the cold zone of the Eastern and Northern hemispheres of the world, in the central part of Central Asia (fig.1) it occupies a total area of 157567758.6 ha between $410-520 \mathrm{~N}$ and West longitude 870-1190 E, on the border of the vast desert behind the Siberian taiga and the Himalayas, with an elongated

\footnotetext{
* Corresponding author
} 
area along the latitude and it is a place with unique natural conditions (Batchuluun E et al., 2020). The total area is 1000$1500 \mathrm{~m}$ above sea level, with mountains in the western, northern, and northeastern parts. Mongolia is with an administrative unit consisting of the capital city Ulaanbaatar and 21 aimags. As of 2020, the total population is 3.38 million (NSO, 2021), the national average population density is 2.1 (1.0 in the Western region, 1.6 in the Khangai region, 1.1 in the Central region, 0.8 in the Eastern Region, and 339.8 in Ulaanbaatar), and 46 percent of the total population live in Ulaanbaatar. The capital city of Ulaanbaatar and 21 provinces are connected by paved roads and the shortest railway connecting Asia and Europe passes through Mongolia. The railway, which connects Asia and Europe, is an important hub for the three countries' economic corridors and an important region for Mongolia's raw materials, industry, and transportation.

Products of the mineral industry and mining industry occupy 10.0 trillion MNT or 85.4 percent of total products sold in foreign markets of Mongolia. Products of the metal ore mining sector occupies 60.2 percent, coal mining products 33.7 percent, oil production products 4.2 percent, and other mining products 1.8 percent of total products sold in foreign markets of Mongolia (NSO, 2020).

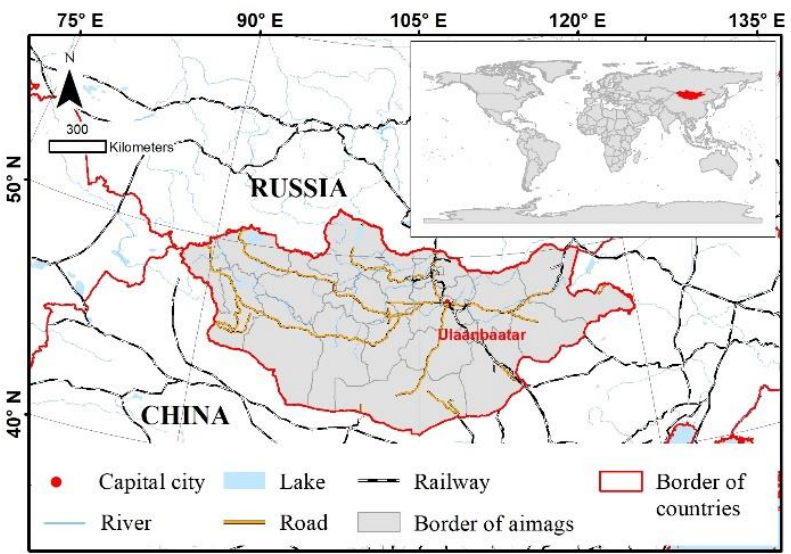

Figure 1. Location of study area

\subsection{Data used for the study}

The study used 21 criteria with 4 sets of factor influence and 7 constraint factors that influence determining a region suitable to establish the metallurgical and steel processing industry (table 1). Mineral resources and natural resources - The iron ore deposit is the main raw material resource to establish the metallurgical and steel processing industry and Mongolia has 1 billion tons of ore reserves (MRPA, 2013).

In this study, iron ore deposits are classified into 3 categories according to the identified reserves and considered separately. 17 deposits with reserves of more than 20000 thous.t, 19 deposits with reserves of 3000-20000 thous.t, 64 deposits, and occurrences with reserves of up to 3000 thous.t were used. Coking coal deposits, which are used to technology to produce high-quality steel and iron billets processing iron ore and fluoride deposits were used as impact indicators. Also, the density of the river network and the underground water potential resources were considered as natural factors influencing the determination of the suitable region.

Infrastructure - Infrastructure has a major impact on the country's industrialization and economic development by reducing production costs, increasing incomes, equitable distribution, and promoting exports (Elijah Udoh et al., 2011). Therefore, the existing and planned railways, roads, power lines, and the location of border crossings with two neighboring countries with access to foreign markets are considered as influencing factors. Consumer Market - The main goals of industrial development policies and programs in Mongolia are to increase foreign trade turnover and economic growth, as well as to meet the grow ing domestic demand every year (Industrialization 21: 100The National Program, 2018). Steel and metal billets are very important issues, that are used in all aspects of the daily life of human society, in infrastructure construction and construction of buildings. Therefore, population density, the center of provinces and soums were used as influencing factors in the domestic market.

\begin{tabular}{|c|c|}
\hline Data & Source \\
\hline Railway, Auto road & $\begin{array}{c}\text { Ministry of Road and } \\
\text { Transport Development, } 2019\end{array}$ \\
\hline $\begin{array}{l}\text { Underground water potential } \\
\text { resources, Special protect area, } \\
\text { Waterbody, Forest, Water source } \\
\text { forming area }\end{array}$ & $\begin{array}{l}\text { Ministry of Environment and } \\
\text { Tourism Mongolia, } 2019\end{array}$ \\
\hline Power line networks & $\begin{array}{c}\text { National Development } \\
\text { Agency, } 2019\end{array}$ \\
\hline Border port & $\begin{array}{c}\text { Agency of the Land affairs, } \\
\text { Geodesy and Cartography, } \\
\text { Mongolia, } 2019\end{array}$ \\
\hline $\begin{array}{l}\text { Population density, Population in } \\
\text { the Center of aimags/soums, } \\
\text { Gross industrial output, Number } \\
\text { of working age population, } \\
\text { Unemployment rate, Poverty } \\
\text { headcount, Private sector value } \\
\text { added share to gross domestic } \\
\text { product, Local budget } \\
\text { investment, Monthly average } \\
\text { wages and salaries, Gross } \\
\text { domestic product per capita }\end{array}$ & $\begin{array}{c}\text { National Statistics Office of } \\
\text { Mongolia,2020 }\end{array}$ \\
\hline Elevation, Slope & $\frac{\text { https://earthexplorer.usgs.gov/, }}{\underline{2017}}$ \\
\hline $\begin{array}{l}\text { Iron ore deposits, Coking coal } \\
\text { deposits, Fluoride deposits, } \\
\text { Density of Groundwater, Lake }\end{array}$ & $\begin{array}{c}\text { National atlas of Mongolia, } \\
2009\end{array}$ \\
\hline
\end{tabular}
Table 1. Used data

Socio-Economic - Tinbergen's theory on industrial location considers the socio-economic cost to plan the industrial location The key factors in determining the location of an industry are socio-economic conditions, long-term local investment, and a stable workforce (Norjmaa T., 1973), all of which play an important role in maintaining and strengthening industrial competitiveness and increasing production efficiency (Urban Lindgren. 1999). For this reason, Gross industrial output, Number of the working-age population, Unemployment rate, Poverty headcount, Private sector value-added share to gross domestic product, Local budget investment, Monthly average wages and salaries, Gross domestic product per capita were used influencing factors the determination of the suitable region.

Constraint - Following the "Law of Mongolia on Special Protected Areas", the "Law on protected zone of water source forming area, waterbody and forest" and the "Law on Water", in areas are included in this categories since the operation of the industry is prohibited. Therefore, Special protect area, Waterbody, Forest, Water source forming area, lake were used as a limiting factor.

Elevation, Slope were used as limiting factors due to the high economic cost of operating factories and facilities in areas with an altitude of more than $2000 \mathrm{~m}$ and a surface slope of more than 25 degrees. 


\subsection{Classification of criteria}

Each of the factors that influences the determination of a suitable area for the establishment of a metallurgical and steel processing industry is classified into three categories: highly suitable, suitable and unsuitable (table 3 ).

\begin{tabular}{lc}
\hline \multicolumn{1}{c}{ Constraint } & Unsuitable \\
\hline State protect area & area \\
Water body & area \\
Forest & area \\
Water source forming area & area \\
Elevation & $2000 \mathrm{~m}<$ \\
Lake & $5 \mathrm{~km}$ \\
Slope & $25^{\circ}<$ \\
\hline
\end{tabular}

Table 2. Constraint factor

\subsection{Method}

The study used 21 influencing factors and 7 limiting factors to determine a suitable a region, that is suitable to establish metallurgical and steel processing industry.

For each factors, a raster image was generated using the ArcToolbox-Conversion tool - Polygon to raster command and the weight value was output using the AHP tool.

In the study were used the Spatial Multi citeria decision analysis (MCDA) method. Multi-criteria decision analysis is a method of geographic information system that comprehensively analyzes and calculates many spatial conditional problems.

When multiple factors are used in the suitability assessment, multivariate analysis uses a method to find the weighted values of factors. When comparing many factors, one is more important than the other and weighs more in terms of weight.

\begin{tabular}{|c|c|c|c|c|c|c|c|}
\hline \multirow[t]{2}{*}{ Factor } & \multicolumn{3}{|r|}{ Criteria } & Unit & \multirow{2}{*}{$\begin{array}{c}\begin{array}{c}\text { Highly } \\
\text { suitable }\end{array} \\
0-50 \mathrm{~km}\end{array}$} & \multirow{2}{*}{$\begin{array}{c}\text { Suitable } \\
50-100 \mathrm{~km}\end{array}$} & \multirow{2}{*}{$\begin{array}{c}\text { Unsuitable } \\
100 \mathrm{~km}<\end{array}$} \\
\hline & $\mathrm{R} 1$ & Iron ore depos & (Resource: more than $20 \mathrm{mln} . \mathrm{t}$ ) & $\mathrm{km}$ & & & \\
\hline \multirow{6}{*}{$\begin{array}{l}\text { Mineral } \\
\text { resources } \\
\text { and natural } \\
\text { resources }\end{array}$} & $\mathrm{R} 2$ & Iron ore depos & (Resource: 3-20 mln.t) & $\mathrm{km}$ & $0-30 \mathrm{~km}$ & $30-75 \mathrm{~km}$ & $75 \mathrm{~km}<$ \\
\hline & R3 & Coking coal de & osits & $\mathrm{km}$ & $0-25 \mathrm{~km}$ & $25-50 \mathrm{~km}$ & $50 \mathrm{~km}<$ \\
\hline & $\mathrm{R} 4$ & Iron ore depos & (Resource: less than 3 mln.t) & $\mathrm{km}$ & $0-25 \mathrm{~km}$ & $25-50 \mathrm{~km}$ & $50 \mathrm{~km}<$ \\
\hline & R5 & Fluoride depos & & $\mathrm{km}$ & $0-25 \mathrm{~km}$ & $25-50 \mathrm{~km}$ & $50 \mathrm{~km}<$ \\
\hline & R6 & Density of Gro & ndwater & $\begin{array}{l}\mathrm{km} / \mathrm{square} \\
\mathrm{km}\end{array}$ & $0.4<$ & $0.1-0.4$ & $0.1>$ \\
\hline & $\mathrm{R} 7$ & Underground & ter potential resources & $\begin{array}{l}\text { cubic } \\
\text { meter }\end{array}$ & $0.2<$ & $0.01-0.2$ & $0.01>$ \\
\hline \multirow{12}{*}{ Infrastructure } & I1 & Railway & Present & \multirow{2}{*}{$\mathrm{km}$} & $0-50 \mathrm{~km}$ & $50-100 \mathrm{~km}$ & $100 \mathrm{~km}<$ \\
\hline & \multirow{7}{*}{$\mathrm{I} 2$} & \multirow{7}{*}{$\begin{array}{l}\text { Power line } \\
\text { networks }\end{array}$} & Planned & & $0-25 \mathrm{~km}$ & $25-50 \mathrm{~km}$ & $50 \mathrm{~km}<$ \\
\hline & & & $35 \mathrm{kwt}$ line & \multirow{6}{*}{$\mathrm{km}$} & $0-10 \mathrm{~km}$ & $10-20 \mathrm{~km}$ & $20 \mathrm{~km}<$ \\
\hline & & & 110 kwt line & & $0-15 \mathrm{~km}$ & $15-35 \mathrm{~km}$ & $35 \mathrm{~km}<$ \\
\hline & & & $220 \mathrm{kwt}$ line & & $0-25 \mathrm{~km}$ & $25-50 \mathrm{~km}$ & $50 \mathrm{~km}<$ \\
\hline & & & Planned 35 kwt line & & $0-10 \mathrm{~km}$ & $10-20 \mathrm{~km}$ & $20 \mathrm{~km}<$ \\
\hline & & & Planned 110 kwt line & & $0-15 \mathrm{~km}$ & $15-35 \mathrm{~km}$ & $35 \mathrm{~km}<$ \\
\hline & & & Planned 220 kwt line & & $0-25 \mathrm{~km}$ & $25-50 \mathrm{~km}$ & $50 \mathrm{~km}<$ \\
\hline & \multirow[t]{2}{*}{$\mathrm{I} 3$} & \multirow{2}{*}{$\begin{array}{l}\text { Border } \\
\text { point/port }\end{array}$} & Temporary activity & \multirow{2}{*}{$\mathrm{km}$} & $0-50 \mathrm{~km}$ & - & $50 \mathrm{~km}<$ \\
\hline & & & Seasonal activity & & $0-30 \mathrm{~km}$ & - & $30 \mathrm{~km}<$ \\
\hline & \multirow[t]{2}{*}{$\mathrm{I} 4$} & \multirow[t]{2}{*}{ Auto road } & Present & \multirow{2}{*}{$\mathrm{km}$} & $0-50 \mathrm{~km}$ & $50-100 \mathrm{~km}$ & $100 \mathrm{~km}<$ \\
\hline & & & Planned & & $0-30 \mathrm{~km}$ & $30-70 \mathrm{~km}$ & $70 \mathrm{~km}<$ \\
\hline \multirow{7}{*}{$\begin{array}{l}\text { Consumer } \\
\text { Market }\end{array}$} & M1 & Population den & & person & $2.0<$ & $0.9-2$ & $0.9>$ \\
\hline & \multirow[t]{6}{*}{ M2 } & \multirow{6}{*}{$\begin{array}{l}\text { Population in } \\
\text { the center of } \\
\text { aimags/soums }\end{array}$} & Center with population less than 3000 & $\mathrm{~km}$ & $10-15 \mathrm{~km}$ & - & $\begin{array}{l}0-10 \mathrm{~km} \\
15 \mathrm{~km}<\end{array}$ \\
\hline & & & Center with population more than 3000 & $\mathrm{~km}$ & $10-20 \mathrm{~km}$ & - & $\begin{array}{l}0-10 \mathrm{~km} \\
20 \mathrm{~km}<\end{array}$ \\
\hline & & & Center with population less than 15000 & $\mathrm{~km}$ & $10-30 \mathrm{~km}$ & - & $\begin{array}{l}0-10 \mathrm{~km} \\
30 \mathrm{~km}<\end{array}$ \\
\hline & & & Center with population $15000-50000$ & $\mathrm{~km}$ & $20-50 \mathrm{~km}$ & - & $\begin{array}{l}0-20 \mathrm{~km} \\
50 \mathrm{~km}<\end{array}$ \\
\hline & & & $\begin{array}{l}\text { Center with population more than } \\
50000\end{array}$ & $\mathrm{~km}$ & $30-70 \mathrm{~km}$ & - & $\begin{array}{l}0-30 \mathrm{~km} \\
70 \mathrm{~km}<\end{array}$ \\
\hline & & & Capital City (Ulaanbaatar) & $\mathrm{km}$ & $40-100 \mathrm{~km}$ & - & $\begin{array}{l}0-40 \mathrm{~km} \\
100 \mathrm{~km}<\end{array}$ \\
\hline \multirow{8}{*}{$\begin{array}{l}\text { Socio- } \\
\text { economic }\end{array}$} & $\mathrm{S} 1$ & \multicolumn{2}{|c|}{ Gross industrial output } & mln.tug & $115<$ & $115>$ & - \\
\hline & $\mathrm{S} 2$ & \multicolumn{2}{|c|}{ Number of working age population } & person & $1500<$ & $1500>$ & \\
\hline & $\mathrm{S} 3$ & \multicolumn{2}{|c|}{ Unemployment rate } & Percent & $7.5<$ & $7.5>$ & - \\
\hline & $\mathrm{S} 4$ & \multicolumn{2}{|c|}{ Poverty headcount } & Percent & $30<$ & $30>$ & - \\
\hline & S5 & \multicolumn{2}{|c|}{$\begin{array}{l}\text { Private sector value added share to gross domestic } \\
\text { product }\end{array}$} & Percent & $82<$ & $82>$ & - \\
\hline & S6 & \multicolumn{2}{|c|}{ Local budget investment } & mln.tug & $8000<$ & $8000>$ & - \\
\hline & $\mathrm{S} 7$ & \multicolumn{2}{|c|}{ Monthly average wages and salaries } & thous.tug & $800<$ & $800>$ & - \\
\hline & S8 & Gross domesti & oroduct per capita & mln.tug & $6<$ & $6>$ & - \\
\hline
\end{tabular}

Table 3. Evaluation of the multi-variable criteria parameters 
AHP (analytical hierarchy process) was used to rank the indicators (Saaty 1977). This method determines the weight value using a criterion ranking matrix.

The multi-factor analysis method is based on geographic information system technology (Baban S.M.J. et al., 2003).

Multi-factor analysis of location suitability is performed using a weighted average using AHP (hierarchical analysis method) tool and AHP is a mathematical method for calculating multiconditional factors in a comprehensive analysis of decisionmaking problems. Another advantage of the AHP method is that it prioritizes the importance of each criterion and produces a realistic weighted average in an easy way. The suitability index for each layer is calculated by the following formula.

$$
S_{i}=\sum X_{i} W_{i}
$$

where

$$
\mathrm{Xi}^{-} \text {the value of the indicator }
$$

$\mathrm{W}_{\mathrm{i}-\text { the weight value of the indicator }}$

The combined comparison method is used to find the weighted percentage.The accuracy of the assessment is indicated by the compliance index $\mathrm{CI}$ and the compliance ratio $\mathrm{CR}$. If $\mathrm{CR}<0.1$, the evaluation is considered appropriate. The weight value is calculated by the following formula using the ranking matrix of the selected factors is sorted by importance. where

CR- Consistency ratio (Saaty 1977)

RI- Random index (Saaty 1977).

CI- Consistency index

$$
C I=\frac{\lambda_{\max }-n}{n-1}
$$

where

$$
\lambda_{\max } \text { - The specific value of the matrix }
$$$$
\text { n- Number of matrix members (Saaty 1977) }
$$

If $\mathrm{CR}>0.1$ is the weight ratio is unreliable and the weight must be recalculated. If $\mathrm{CR} \leq 0.1$ is the weight ratio is correct and the analysis process continues. The sum of the scales is equal to one. After determining the weight values for each factor, an integrated evaluation image was generated using the ArcToolbox-Spatial Analyst Tools-Map Algebra-Raster Calculator tool.

The accuracy of the classification map is determined by how accurately it describes reality and representing (Foody, 2002).

$$
\text { kappa coefficient } k=\frac{n \sum_{k=1}^{q} n_{k k}-\sum_{k=1}^{q} n_{k+} n_{+k}}{n^{2}-\sum_{k=1}^{q} n_{k+} n_{+k}}
$$

where $n_{k}-$ sum of class

Cohen's kappa ( $\kappa)$ can range from -1 to +1 (Altman 1999)

$$
C R=C I / R I
$$

\section{Suitable region evaluation for industrial development}

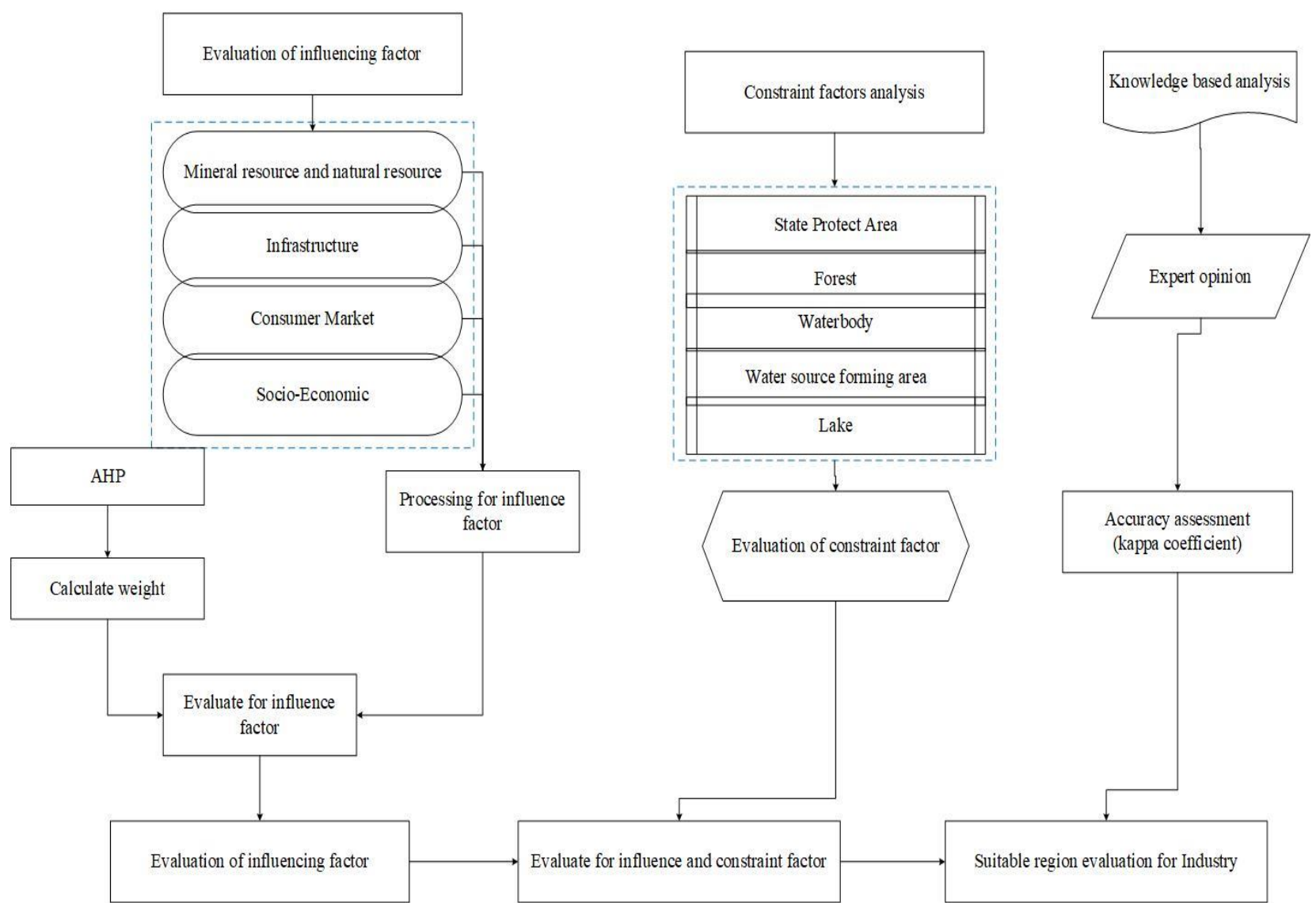

Figure 2. The approach of suitable location evaluation for the metallurgical and steel processing industries 


\section{RESULT AND DISCUSSION}

21 criteria including mineral resources and natural resources, infrastructure, consumer markets and socio-economic factors that influence the identification of suitable regions for metallurgical and steel processing industries in throughout Mongolia were selected and mapped using GIS-based MCDA and AHP methods.
Within the framework of surface conditions and relevant laws and regulations of Mongolia calculated and released results excluding 68.8 percent (108448353.8 ha) of the total area of the 7 criteria for restricting heavy industrial activities.

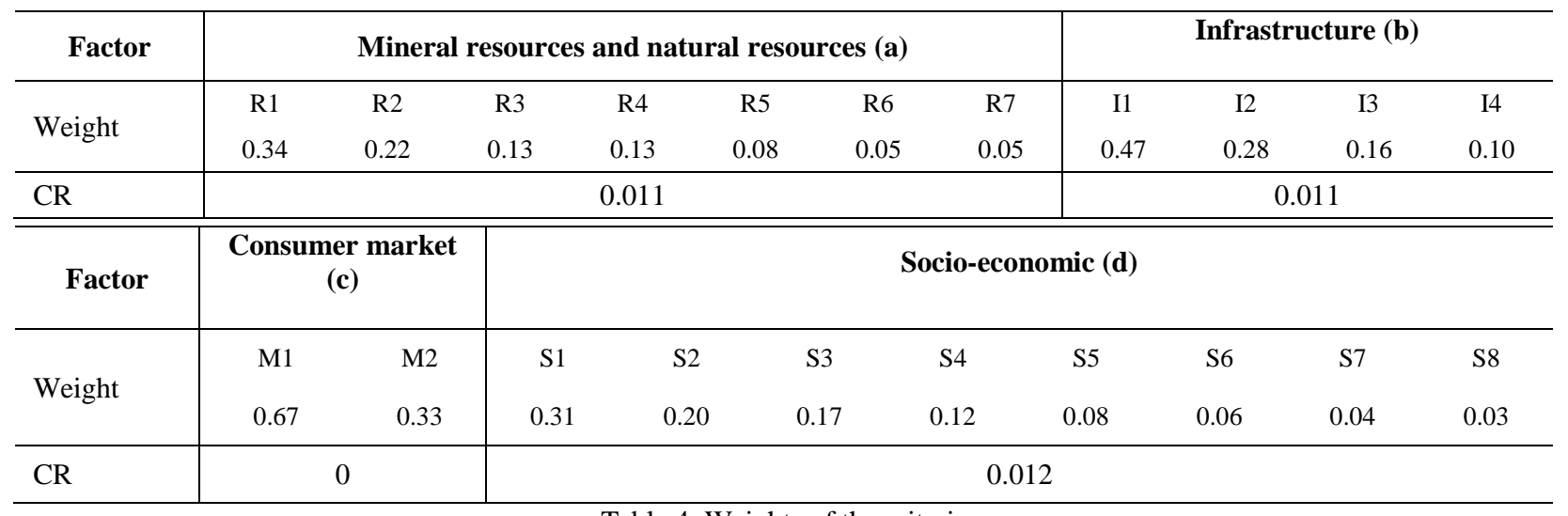

Table 4. Weights of the criteria
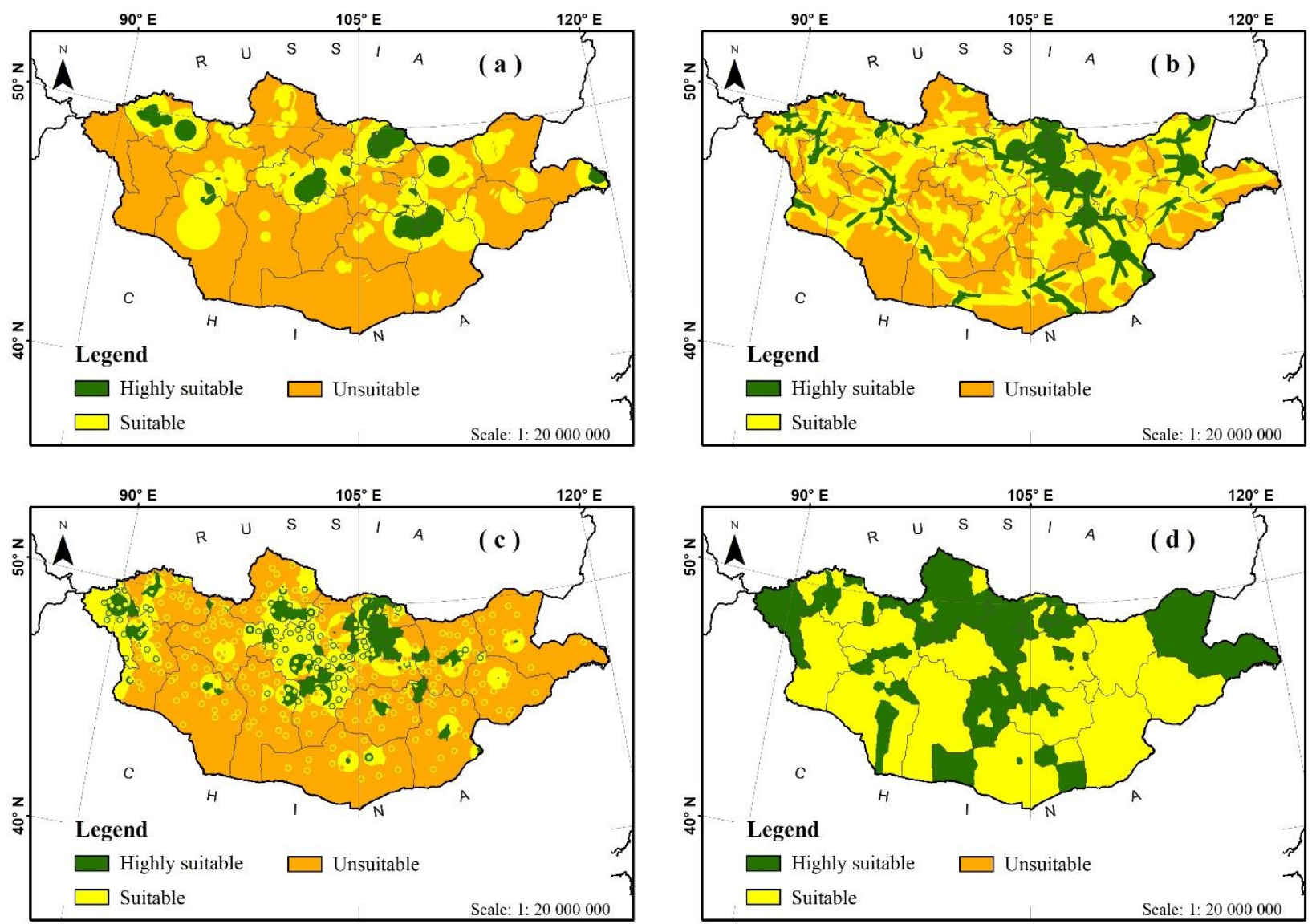

Figure 3. Suitability classification map of criteria (a) factors of mineral resources and natural resources, (b) factors of infrastructure, (c) factors of consumer market, (d) factors of socio-economic 


\begin{tabular}{lcccccc}
\hline \multicolumn{1}{c}{ Factor } & \multicolumn{2}{c}{ Highly suitable } & \multicolumn{2}{c}{ Suitable } & \multicolumn{2}{c}{ Unsuitable } \\
& Area (thous.ha) & Percent & Area (thous.ha) & Percent & Area (thous.ha) & Percent \\
\hline Mineral resources & 5803.6 & 3.7 & 23883.3 & 15.2 & 56779.3 & 36.0 \\
and natural resources & 14990.1 & 9.5 & 42021.7 & 26.7 & 29872.0 & 19.0 \\
Infrastructure & 7842.9 & 5.0 & 17928.6 & 11.4 & 60707.4 & 38.5 \\
Consumer market & 26319.8 & 16.7 & 60219.6 & 38.2 & - & - \\
Socio-Economic & & &
\end{tabular}

Table 5. Suitability classification result of factors

\subsection{Evaluation of criteria}

The tables 4 and fig. 3 show the weights and consistency ratios of the factors in each criterion.

When assessed the 7 factors included in the mineral resource and natural resource criteria, the consistency ratio (CR) was 0.011 (table 4) and 3.7 percent of the total survey area was highly suitable, 15.2 percent was suitable and 36 percent was unsuitable. The highly suitable and suitable areas are more widespread in the central part of the study area, while they are less widespread in the western and eastern parts (table 5 and fig 3 ).

The consistency ratio (CR) was 0.011 when evaluated the 4 factors included in the infrastructure criteria. According to this assessment, 9.5 percent of the survey area is highly suitable, 26.7 percent is suitable, and 19 percent is unsuitable and due to the location of railways and power transmission lines, which are the main influencing factors, the spread of the most suitable areas in the central part of Mongolia is high (table 5 and fig 3 ).

Consistency ratio (CR) was 0.0 when the consumer market criteria evaluated two factors that determine the purchasing power of manufactured products. 5 percent of the study area is highly suitable, 11.4 percent is suitable, and 38.5 percent is unsuitable (table 5 and fig 3 ).

There is the spread of highly suitable area in the central part of Mongolia, while the spread of suitable areas in the west is high. When assessed the 8 factors included in the socio-economic criteria, the consistency ratio (CR) was 0.01 and 16.7 percent of the total survey area was highly suitable and 38.2 percent was suitable (table 5 and fig 3 ).

\subsection{Suitable region evaluation for metallurgical and steel processing industry}

Table 6 shows the weight values of the indicators and consistency ratios. As a result of our research, the most suitable area for the establishment of a metallurgical and steel processing industry in Mongolia is 9.8 percent (15476217.08 ha) of the total survey area (fig. 4).

The most suitable area is well distributed in the central part of the study area and has a certain spread in the western and eastern parts, while the spread of the most suitable area in the southern part of the study area is very small. Suitable regional area is 22.7 percent (35742642.07 ha) of the total area (fig 4).

The survey results show that the suitable and the most suitable areas for the establishment of metallurgical and steel processing industry are close to iron ore deposits and these areas are with a relatively high potential for a population-centered market connected to existing railways and electricity.

The area of unsuitable areas is 22.4 percent ( 35236417.31 ha) of the total area.

The iron ore deposit, which is the main raw material resource, is relatively evenly spread in our country, but due to other factors influencing the establishment of production, the share proportion of the most suitable and the suitable area in the southern part of the study area is small.

\begin{tabular}{lcc}
\hline \multicolumn{1}{c}{ Criteria } & Value & CR \\
\hline Mineral resource and natural & 0.46 & \\
resource & 0.26 & 0.004 \\
Infrastructure & 0.14 & \\
Market & 0.14 & \\
Socio-economic &
\end{tabular}

Table 6. Weights of factors influencing for metallurgical and steel processing industry

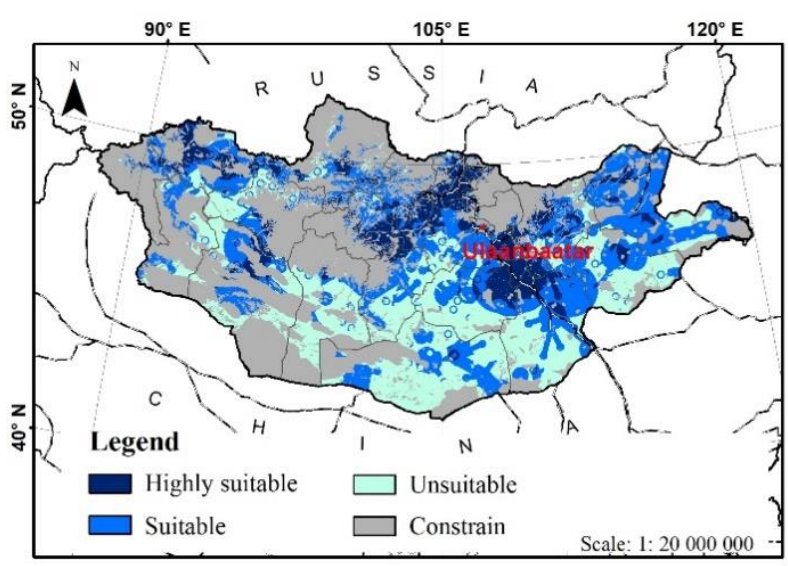

Figure 4. Suitability classification map for metallurgical and steel processing industry

\subsection{Validation}

According to the report (Licensing report for 2014-2020 issued by the Mongolian Construction Materials Manufacturers Association, and a report "Needs, necessities, opportunities and solutions for cluster development of the metallurgical industry 2016" issued by the Ministry of Industry, Mongolia and the National Industry Council), there are 24 companies in Mongolia that produce steel and metal products using iron ore and scrap metal (fig 5).

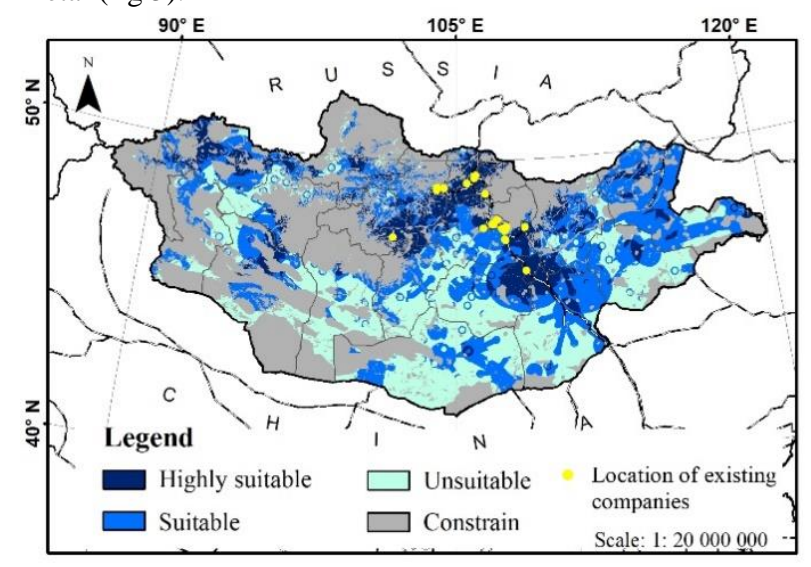

Figure 5. Spatial distribution of validation data 
The kappa coefficient was calculated by comparing suitability classification map with the locations of 24 metallurgical and steel processing companies. The Kappa coefficient determines the exact correspondence between the classification map and the real class on the ground. As a result of the validation, the kappa coefficient was 0.84 , which suggests that the suitability evaluation map was accurately mapped.

\section{CONCLUSION}

Recently, when a sustainable development is considered in many countries need to plan new industry by choosing a location based not only on economic indicators.

Especially for Mongolia, which has a vast territory and ecological advantages, taking into account indicators that comprehensively consider economic, social and environmental issues and mapping the location of production will be a key factor in the sustainable development of the industry.

Our research has advantage determining the suitable regions for the metallurgical and steel processing industry in Mongolia using GIS based multi criteria decision analysis and analytical hierarchical analysis method. In order to determine the suitable region for metallurgical and steel processing industries used total of 28 criteria, 21 influencing criteria based on mineral resources and natural resources, infrastructure network, consumer market location, and local socio-economic condition, 7 constraint criteria based on area where industries and activities are prohibited in accordance with the legislation of Mongolia. According to the survey, 9.8 percent of the total area of Mongolia is considered to be highly suitable, 22.7 percent is suitable and 22.4 percent is unsuitable for metallurgical and steel processing industries.

The results of this study will be an important background information in the activities such as to create economic growth that supports the sustainable development of the country through industrial planning based on scientific methods, as well as to produce export-oriented and import-substituting products, to reduce urban agglomeration and to build industrial planning that will support the improvement of living standards.

\section{ACKNOWLEDGEMENTS}

We would like to thank the research team of the Institute of Geography and Geoecology of the Mongolian Academy of Sciences, who helped in this research.

\section{REFERENCES}

Aleksandar Rikalovic, Ilija Cosic, Djordje Lazarevic (2014). GIS Based Multi-Criteria Analysis for Industrial Site Selection. 24th DAAAM International Symposium on Intelligent Manufacturing and Automation, 2013, Procedia Engineering 69, $1054-1063$

Alexandre de Oliveira Gomes, Carlos Alberto Nunes Cosenza. 2015. Smart Decision in Industrial Site Selection: What's New in the Case of a Steel Mill in Brazil?. Springer International Publishing Switzerland, DOI 10.1007/978-3-319-14078-0_4

Altman, D. G., 1999. Practical statistics for medical research. New York, NY: Chapman \& Hall/CRC Press.

Amita Johar, S.S Jain and P.K Garg (2013) Land suitability analysis for industrial development using GIS, Journal of Geomatics, Vol.7 No.2 October 2013, 101-106
Baban S.M.J., Wan-Yusof K., 2003. Modelling optimum sites for locating reservoirs in tropical environments. Water Resources Management 17 (1), 1-17

Batchuluun E (red), 2020. The physical geography of Mongolia, Ulaanbaatar, Mongolia, Munkhiin useg publication, p19 p480

Elijah Udoh, Uchechi R Ogbuagu, Uwem Essia, Ignatius I Ukpong, John E Udo Ndebbio, 2011. Industrial development : a catalyst for rapid economic growth : essays in honour of John Emmanuel Udo Ndebbio, Ph. D., our retired Professor of Economics, Department of Economics, University of Calabar, Calabar, Nigeria, P.N. Davison Publications, Nigeria

Foody Giles M. 2002. Status of land cover classification accuracy assessment. Remote Sensing Environment 80. 185-201

Hadeal H. Alzamili, Mahmoud El-Mewafi , Ashraf M. Beshr, Ahmed Awad. 2015. GIS Based Multi Criteria Dicesion Analysis for Industrial Site Selection in Al-Nasiriyah City in Iraq, International Journal of Scientific \& Engineering Research, Volume 6, Issue 7, July-2015, DOI: 10.13140/RG.2.1.4883.2480

Industrialization 21: 100, 2018. The National Program, Mongolia

Marzieh Reisi1, Lu Aye, Alireza Soffianian. 2011. Industrial Site Selection by GIS in Isfahan, Iran. 19th International Conference on Geoinformatics, Shanghai, China DOI: 10.1109/GeoInformatics.2011.5981171

Mineral resources and petroleum authority (MRPA), 2013. Report of Iron ore mining and market outlook, Ulaanbaatar

Ministry of Industry, Mongoilia and the National Industry Council, 2016, Report "Needs, necessities, opportunities and solutions for cluster development of the metallurgical industry", Ulaanbaatar, Soyombo publication, 35-102

National Statistical Office of Mongolia, 2018. Report of Industry-2017, Ulaanbaatar

National Statistical Office of Mongolia, 2020. Report of Industry-2019, Ulaanbaatar

National Statistical Office of Mongolia, 2021. Population-2021, Ulaanbaatar

Natsagdorj B., 1975. Location and development of industry, Ulaanbaatar, 4-56

Norjmaa T., 1973, Industrial geography of Mongolia, Mongolian academy of sciences publication, 11-81

Urban Lindgren. 1999. Simulating the Long-Term Labour Market Effects of an Industrial Investment. Erdkunde archive for scientific geography, 53, 150-162. 